\title{
Assessing Water Quality of Rural Water Supply in Thailand
}

\author{
K. Soticha, Y. Jareeya, K. Sudjit, and P. Prapat
}

\begin{abstract}
The water quality of water supply is closely associated with human health. And providing safe water supply is one of important public health priorities. Providing water supply to small rural communities in Thailand is mainly through two types of rural water supply systems, groundwater supply system and surface water supply system. The objective of this paper is to measure the water quality to assess existing performance of rural water supply system for small rural community. Twenty five rural water supply locations in four provinces, Nakhon Ratchasima, Chaiyaphum, Buriram and Surin province of Northeastern area in Thailand were selected as sampling location. The water samples from each sampling points were measured physical, chemical and biological parameters. The sampling points were water resource, storage tank and household of each rural water supply location. The results of water quality were assessed to meet the water supply quality standard of the World Health Organization (WHO) and national surface water and groundwater quality standard. The results of water resource quality indicated that the groundwater resource quality was found to be limit exceeded more than surface water resource. It might be contaminated by human or animal. And the results of storage tank and household water qualities indicated that both rural water supply systems had problems to produce the water supply that meet the standard especially in biological standard. It indicated a failure in the disinfection process. As the results of study support that the process of rural water supply system should be improved especially the disinfection process.
\end{abstract}

Index Terms-Water quality, rural water supply system, water surface, groundwater.

\section{INTRODUCTION}

The water quality of water supply is closely associated with human health. And providing safe water supply is one of important public health priorities. There are over 783 million people, lack access to safe water [1], [2]. Access to safe water is a basic concern for human health and health protection. Thus, if the water was contaminated by pollutants, it would affect the quality of water supply and affect the health of the population because of the water borne diseases [3], [4]. Some water-related infectious diseases, such as diarrheal diseases are cause of human morbidity and mortality [5]. Providing safe water supply is one of important public health priorities. Providing water supply to small rural communities in Thailand is mainly through two types of rural water supply

Manuscript received April 15, 2013; revised July 11, 2013

K. Soticha, Y. Jareeya, and K. Sudjit are with School of Environmental Engineering, Institute of Engineering, Suranaree University of Technology, Nakhon Ratchasima, 30000, Thailand (e-mail: chareeya@sut.ac.th).

Prapat Pentamwa is with School of Environmental Health, Institute of Medicine, Suranaree University of Technology, Nakhon Ratchasima, 30000 Thailand.(e-mail: pentamwa@sut.ac.th). systems, groundwater supply system and surface water supply system. The objective of this paper is to measure the water quality to assess existing performance of rural water supply system for small rural community. This study purpose is to investigate water quality of rural water supply in the Northeastern part of Thailand, Nakhon Ratchasima, Chaiyaphum, Buriram and Surin province. They were selected as sampling locations. The rural water supply systems in Thailand usually use the slow sand filtration method. It had been considered for rural water supply because of its simplicity, reliability and economy and suitable for small rural community. Slow sand filtration is water purification process in which water is percolated slowly through porous bed of filter media, followed by flocculation and setting unit [6], [7]. The rural water supply system was classified in two types by water resource, groundwater and surface water system.

The water surface system consisting of rapid mixing, slow mixing, sedimentation filtration, chlorination, storage tank and distribution system and the groundwater system consisting of storage tank and distribution system. Thus, there is a strong need to assess the water quality to determine possible improvement in performance of rural water system in Thailand. The existing water supply system is suitable for small and low income group community rural supply system or should improve the performance to produce for safe water supply.

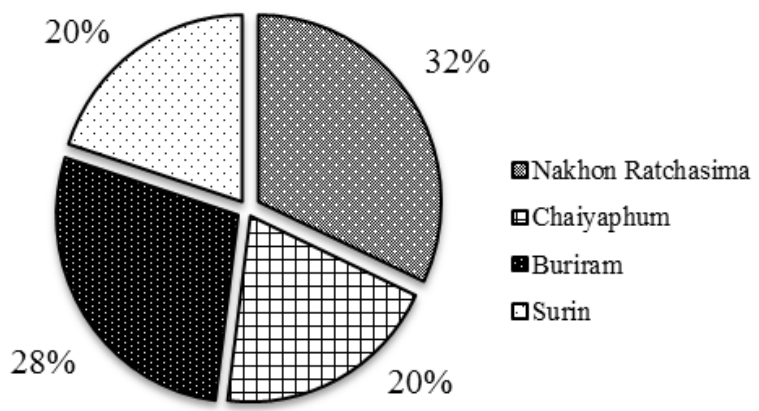

Fig. 1. The percentage of sampling rural water supply.

\section{METHODS}

Twenty five rural water supply locations in four provinces, Nakhon Ratchasima, Chaiyaphum, Buriram and Surin in province of Northeastern area in Thailand were selected as sampling location. The water sampling was carried in rainy season during July to September 2012. The sources of raw water of percentage of sampling rural water supply locations each province are shown in Table I and Fig.1. Both types of water supply system were sampling, 15 surface water system 
locations and 10 groundwater system location. The water sample from each sampling points were collected at water resource, storage tank and the pipe of household. Water analysis was performed in accordance with procedure described in Standard Methods of Water and Wastewater Examination [8]. The water samples were measured color, turbidity, temperature, $\mathrm{pH}$, conductivity, TS, TSS, TDS, DO,
$\mathrm{BOD}_{5}$, chlorine residual, nitrate, nitrite, iron, manganese, calcium and magnesium hardness, fluoride ammonia, TKN, Total coliform and fecal coliform. The water quality results were assessed the performance of water supply system by using the water supply quality standard of the World Health Organization (WHO) and national surface water and ground quality standard [9].

TABLE I: NUMBER AND RATIO OF RURAL WATER SUPPLY LOCATIONS IN FOUR PROVINCES

\begin{tabular}{|c|c|c|c|c|c|c|}
\hline \multirow{2}{*}{ Province } & \multicolumn{2}{|c|}{ Numbers of water supply system sampling } & \multicolumn{3}{c|}{ Ratio of water supply system sampling (\%) } \\
\cline { 2 - 7 } & Number & Groundwater & Surface water & Ratio & Groundwater & Surface water \\
\hline Nakhon Ratchasima & 8 & 4 & 4 & 2.00 & 16.00 \\
\hline Chaiyaphum & 5 & 2 & 3 & 28.00 & 16.00 \\
\hline Buriram & 7 & 3 & 4 & 20.00 & 12.00 \\
\hline Surin & 5 & 1 & 4 & 100 & 16.00 \\
\hline total & 25 & 10 & 15 & & 100 \\
\hline
\end{tabular}

TABLE II: THE RESUlts OF PHYSICAL, CHEMICAL AND BIOLOGICAL WATER QUALiTy SAMPLES

\begin{tabular}{|c|c|c|c|c|c|c|c|c|}
\hline & & & Physical Cl & eristic $(\%)$ & Chemical C & teristic $(\%)$ & Biological & cteristic $(\%)$ \\
\hline Samp & point & $n$ & Not oyoed & Limits & Not oycoed & Limits & Not oyooed & Limits \\
\hline Dortasos & Groundwater & 9 & 55.56 & 44.44 & 100 & 0 & 0 & 100 \\
\hline Naw water & Surface water & 15 & 93.33 & 6.67 & 93.33 & 6.67 & 100 & 0 \\
\hline & Groundwater & 2 & 50 & 50 & 100 & 0 & 0 & 100 \\
\hline & Surface water & 14 & 14.29 & 85.71 & 78.57 & 21.43 & 57.14 & 42.86 \\
\hline & Groundwater & 10 & 70 & 30 & 100 & 0 & 20 & 80 \\
\hline & Surface water & 15 & 46.67 & 53.33 & 93.33 & 6.67 & 53.33 & 46.67 \\
\hline
\end{tabular}

\section{RESUlTS AND DiSCUSSION}

As shown in Table II, the water resource quality results of surface water system are much better than groundwater resource especially in physical and biological characteristics. The raw water from groundwater system showed $100 \%$ limits exceeded in biological characteristics. These results indicated the groundwater resource is contaminated by human or animal because of the presence of Total coliform and fecal coliform. The physical characteristic of water surface samples is relatively high average $46.49 \mathrm{Pt}-\mathrm{Co}$ of color.

In surface water system, the number of limits exceeded water samples in physical characteristics increased from storage tank sampling point to household sampling point. The percentage of limit exceeded water samples were increased from 14.29 to 46.67 respectively. And the number of limits exceeded water samples in biological characteristics of storage tank sampling point were similarly, the household sampling point. The percentage of limit exceeded water samples were 42.86 and 46.67 respectively. These results showed the surface water supply system might be contaminated in distribution system.

In groundwater system, the number of limits exceeded water samples in physical and biological characteristics were high in every sampling point. Total coliform and fecal coliform were found $100 \%$ of limits exceeded at raw water sampling point and storage tank point and $80 \%$ at the household sampling point. The groundwater supply system has no disinfection process therefore when the water resource was contaminated with bacteria, they still shown in storage tank and household sampling point.
Fig. 2 showed the water samples of raw water, storage tank and household sampling points had limits exceeded in physical characteristic especially for groundwater. Color and turbidity are the physical parameters which are limit exceeded in surface water system. Fig. 3 showed the water samples of raw water, storage tank and household sampling points are not exceeded in chemical characteristic. And Fig. 4 showed water qualities of groundwater system are limits exceeded in biological characteristics. Total coliform and fecal coliform

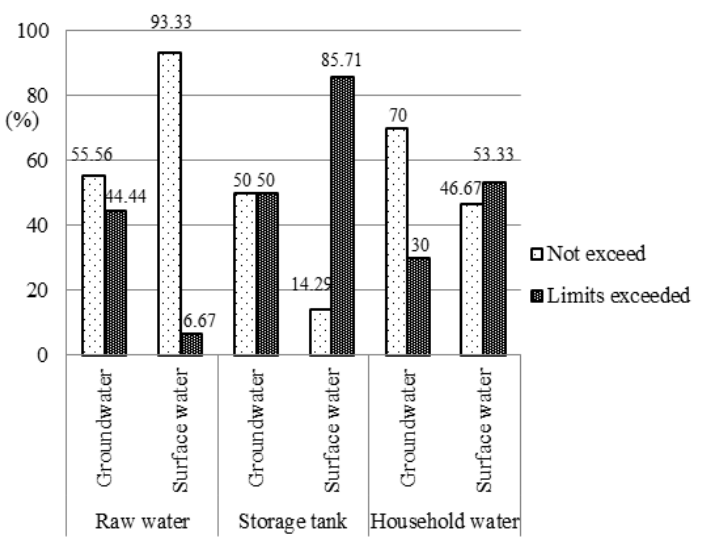

Fig. 2. The physical characteristic of raw water, storage tank and household water qualities from water surface and ground water system

parameters were found to higher than the standard require especially water samples from groundwater system. Water samples were found fecal coliform in range of 4-103 $\mathrm{cfu} / 100 \mathrm{ml}$ for surface water system's samples and in range of 4-155 cfu/100 ml for groundwater system's samples. According to WHO, data on fecal coliform bacteria may be 
grouped into the following risk categories: $0 \mathrm{cfu} / 100 \mathrm{ml}$ (conformity); 1-10 cfu/100 ml (low risk); 10-100 cfu/100 $\mathrm{ml}$ (intermediate risk); $100-1000 \mathrm{cfu} / 100 \mathrm{ml}$ (high risk); and $41000 \mathrm{cfu} / 100 \mathrm{ml}$ (very high risk) [10]. The surface water resources are more likely to be contaminated than those from groundwater. The quality of groundwater from deep boreholes and well is at minimum risk of microbial contamination [11]. The fecal coliform indicator is a key in assessing potential public health risks due to pathogens from water used. However, the presence of fecal coliform in treated water provides an indication of either a failure in the disinfection process, or a strong growth of bio-film in the distribution system, or that the water is prone to surface water infiltration. It is indicated that the water was contaminated by human. The quality of surface water often fluctuates depending on the environmental and climatic conditions and the presence of animal and/or human faecal material [12].

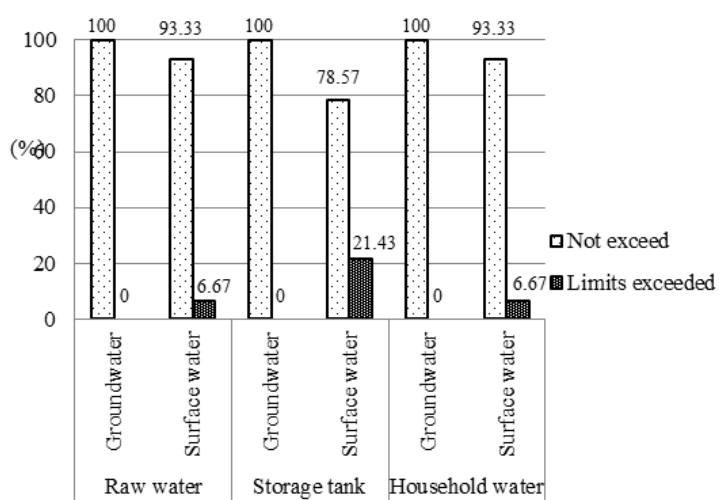

Fig. 3. The chemical characteristic of raw water, storage tank and household water qualities from water surface and ground water system

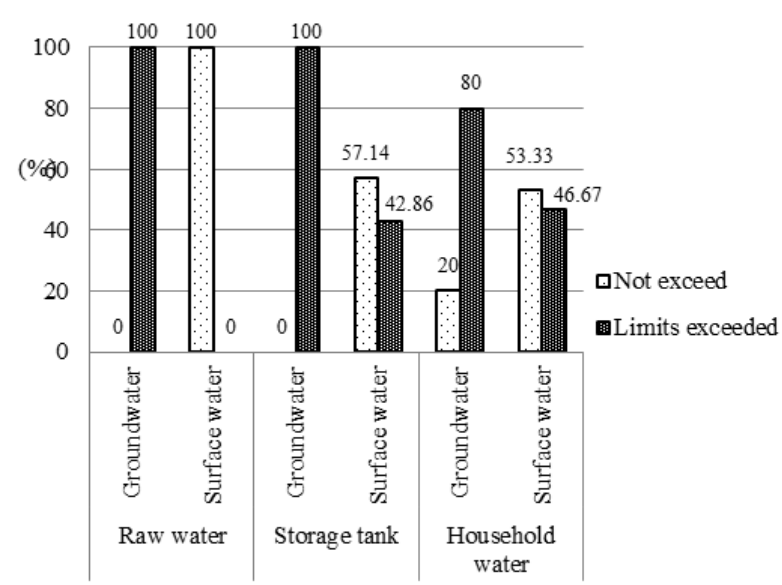

Fig. 4. The biological characteristic of raw water, storage tank and household water qualities from water surface and ground water system

\section{CONCLUSION}

The results of raw water quality indicated that the groundwater quality was found to be limit exceeded than surface water. It might be contaminated between storage tank and household piping (distribution system) by human. And the results of storage tank and household water qualities indicated that both rural water supply systems had problems to produce the water supply that meet the standard especially in biological standard. As the results of study support that the process of rural water supply should be improved especially in disinfection process and the groundwater supply system need to be added the disinfection process for safe water supply.

\section{ACKNOWLEDGMENT}

This work was supported by Suranaree University of Technology.

\section{REFERENCES}

[1] Progress on Drinking Water and Sanitation, UNICEF/WHO, (2012).

[2] United Nations. (2012). The Millenium Development Goals Report 2012. New York, pp. 52-53.

[3] UNICEF/WHO. (20 July, 2011) Diarrhea. Why children are still dying and what can be done. [Online] 2009. Available: http:whqlibdoc.who.intpublications/2009/9789241598415_eng.pdf

[4] J. Bartram and B. Gordon, "The global challenge of water quality and health. Water Pract. Technol.," Water Practice \& Technology, vol. 3, no. 4, 2008.

[5] J. Gasana, J. Morin, A. Ndikuyeze, and P. Kamoso, "Impact of water supply and sanitation on diarrheal morbidity among young children in the socioeconomic and cultural context of Rwanda (Africa)," Environmental Research Section, vol. 90, pp. 76-88, 2002.

[6] R. L. Droste, The Theory and Practice of Water and Wastewater Treatment, New York: Wiley, 1997, pp. 800.

[7] R. E. Arndt and E. J. Wagner, "Filtering Myxobolus cerebralis Triactinomyxons from contaminated water using rapid sand filtration," Aquacultural Engineering, vol. 29, pp. 77-91, 2003.

[8] APHA, AWWA, and WEF, Standard Methods for the Examination of the Water and Wastewater, $21^{\text {th }}$ ed. Washington D.C.: American Public Health Association, 2005.

[9] Guidelines for Drinking-Water Quality, Volume 1, Recommendations, $3^{\text {rd }}$ ed. WHO, 2004.

[10] B. A. Hoque, K. Hallman, J. Levy, H. Bouis, N. Alif, F. Khan, S. Khanam, M. Kabir, S. Hossain, and M. S. Alam, "Rural drinking water at supply and household levels: Quality and management," Int. J. Hyg. Environ.-Health, vol. 209, pp. 451-460, 2006.

[11] H. Y. Richardson, G. Nichols, C. Lane, L. R. Lake, and P. R. Hunter, "Microbiological surveillance of private water supplies in England-The impact of environmental and climate factor on water quality," Water Research, vol. 43, pp. 2159-2168, 2009.

[12] O. C. Shanks, C. Nietch, M. Simonich. M. Younger, D. Reynolds, and K. G. Field, "Basin-wide analysis of the dynamics of fecal contamination and fecal source identification in Tillamook Bay," Oregon Appl. Environ. Microbiol, vol. 72, pp. 5537-5546, 2006.

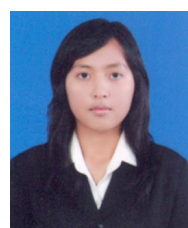

Soticha Kitarsa was born on 18 July, 1986 at Nakhon Ratchasima, Thailand. She had obtained bachelor degree in Environmental Engineering. Present, she is a master student, school of Environmental Engineering, Suranaree University of Technology, Nakhon Ratchasima, Thailand.

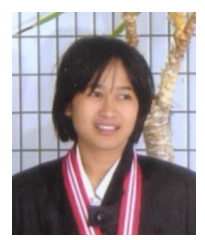

Jareeya Yimrattanabovorn had obtained Ph.D. in Environmental Technology from Ehime University, Japan, 2003. Present, she is a lecturer, school of Environmental Engineering, Institute of Engineering, Suranaree University of Technology, Thailand.

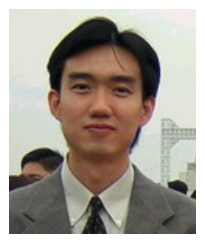

Sudjit Karuchit had obtained Ph.D. in Environmental Engineering from Illinois Institute of Technology, U.S.A., 2001. Present, he is a lecturer, school of Environmental Engineering, Institute of Engineering, Suranaree University of Technology, Thailand.

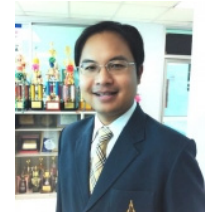

Prapat Pentamwa had obtained Ph.D. in Environmental Engineering and Management), Asian Institute of Technology, Thailand, 2008. Present, he is a lecturer, school of Environmental Health, Institute of Medicine, Suranaree University of Technology, Nakhon Ratchasima, Thailand. 